\title{
Structure Elucidation of Auxofuran, a Metabolite Involved in Stimulating Growth of Fly Agaric, Produced by the Mycorrhiza Helper Bacterium Streptomyces AcH 505
}

\author{
Simone Keller, Kathrin Schneider, Roderich D. Süssmuth
}

Received: August 21, 2006 / Accepted: November 16, 2006

(C) Japan Antibiotics Research Association

\begin{abstract}
Mycorrhiza helper bacterium Streptomyces strain AcH 505 stimulates ectomycorrhiza formation between spruce and fly agaric by supporting fungal growth whereas growth of pathogenic fungi is suppressed. A fungal growth promoting substance was isolated and the chemical structure elucidated by mass spectrometry and NMR spectroscopy. The absolute configuration of the novel fungal growth promoting compound auxofuran (1) was deduced from NMR data with the help of Mosher esters.
\end{abstract}

Keywords mycorrhiza helper bacterium, growth promoting substance, structure elucidation

Intact terrestric ecosystems depend on the ubiquitous symbiosis between plants and fungi called mycorrhiza. Mycorrhizal associations provide the plant with better access to water as well as to nutrients such as phosphorus, nitrogen and iron. Another positive effect for the plant is protection against pathogens and parasites. In boreal, alpine and temperate regions, the predominant form of association between plants and fungi is the ectomycorrhizal symbiosis. Apart from plants and fungi, mycorrhiza often involves bacteria. The so-called mycorrhiza helper bacteria [1] stimulate fungal growth as well as mycorrhiza formation. Isolation and characterization of the substances responsible for these effects will provide a basis for better understanding them. In the present work, a compound produced by the

R. D. Süssmuth (Corresponding author), S. Keller, K. Schneider: Institut für Chemie, Technische Universität Berlin, Straße des 17. Juni 124, D-10623 Berlin, Germany,

E-mail: suessmuth@chem.tu-berlin.de
Streptomyces strain AcH 505 that showed a stimulating effect on the growth of fly agaric (Amanita muscaria) [2 4], thus influencing ectomycorrhiza formation with spruce (Picea abies), was isolated and the structure elucidated.

The taxonomy of the producing Streptomyces strain $\mathrm{AcH}$ 505, fermentation, isolation and biological activities are reported in preceeding papers [2, 3]. For structure elucidation, auxofuran (1) was analyzed by mass spectrometry and NMR spectroscopy. The high-resolution ESI-FTICR mass spectra of 1 showed a mass of $\mathrm{m} / \mathrm{z}$ 195.10197 $\left[(\mathrm{M}+\mathrm{H})^{+}, \mathrm{C}_{11} \mathrm{H}_{14} \mathrm{O}_{3},(\mathrm{M}+\mathrm{H})^{+}\right.$theor $=195.10212$, $\Delta \mathrm{m}=0.77 \mathrm{ppm}]$. Database searches of the molecular formula did not match with any known compound from the DNP database [5] or the CAS-online database [6]. The physico-chemical properties of $\mathbf{1}$ are shown in Table 1.

The ${ }^{1} \mathrm{H}$ and ${ }^{13} \mathrm{C}$ NMR spectral data of compound $\mathbf{1}$ are shown in Table 2. The ${ }^{1} \mathrm{H}$ NMR spectrum showed a methyl group, four methylene groups, a methine group, a hydroxy proton, and an aromatic proton. The ${ }^{13} \mathrm{C}$ NMR data

Table 1 Physico-chemical properties of 1

$\begin{array}{ll}\text { Appearance } & \text { Yellow oil } \\ \text { Molecular formula } & \mathrm{C}_{11} \mathrm{H}_{14} \mathrm{O}_{3} \\ \text { ESI-FTICR }(\mathrm{m} / \mathrm{z}) & \\ \text { Found }[\mathrm{M}+\mathrm{H}]^{+} & 195.10197 \\ \text { Calcd }[\mathrm{M}+\mathrm{H}]^{+} & 195.10212 \\ \mathrm{UV} \lambda_{\max }^{\mathrm{MeOH}}[\mathrm{nm}](\varepsilon) & 272(7992) \\ \text { IR } v_{\max }\left(\mathrm{cm}^{-1}\right) & 3388,2958,2926,2872, \\ & 2855,1744,1714,1669, \\ & 1464,1379,1173,1045, \\ & 1026\end{array}$


supported the presence of these groups and revealed four quaternary carbon atoms. From 2D NMR spectra, we identified compound 1 to be 5,6-dihydro-4-hydroxy-3propyl-4H-benzofuran-7-one (Fig. 1). Connectivities from $\mathrm{OH}-4$ to $\mathrm{H}-4$, from $\mathrm{H}-4$ to $\mathrm{H}_{2}-6$, and $\mathrm{H}_{2}-8$ to $\mathrm{H}_{3}-10$ were established based on analyses of ${ }^{1} \mathrm{H}-{ }^{1} \mathrm{H}$ COSY NMR data (Fig. 2) as well as HMBC NMR data. The positions of the hydroxy and the keto groups were assigned according to HMBC spectra (Fig. 2). HMBC correlation for the proton of the hydroxy group to C-4, C-5 and C-3a suggested that the $\mathrm{OH}$ group is attached to $\mathrm{C}-4$. The absolute configuration was determined by the modified Mosher's method [7] by preparing (S)- and (R)- $\alpha$-methoxy$\alpha$-trifluoromethylphenylacetic acid (MTPA) esters of auxofuran.

$(R)$ - and $(S)$-MTPA esters were prepared as follows: To a solution of auxofuran $(2.9 \mathrm{mg}, 15 \mu \mathrm{mol})$, (dimethylamino)pyridine $(7.3 \mathrm{mg}, 60 \mu \mathrm{mol})$, and triethylamine $(3 \mu \mathrm{l}$, $21 \mu \mathrm{mol})$ in dry dichloromethane $(R)$ - or $(S)$-MTPA

Table $2{ }^{1} \mathrm{H}$ and ${ }^{13} \mathrm{C}$ NMR shifts of auxofuran

\begin{tabular}{clr}
\hline Position & \multicolumn{1}{c}{${ }^{1} \mathrm{H}(\mathrm{J}$ in $\mathrm{Hz})$} & ${ }^{13} \mathrm{C}$ \\
\hline 2 & $7.72(\mathrm{~s})$ & 144.9 \\
3 & - & 125.8 \\
$3 \mathrm{a}$ & - & 140.9 \\
4 & $4.85(\mathrm{ddd}, J=4.3,6.5,6.9)$ & 62.0 \\
$4-\mathrm{OH}$ & $5.37(\mathrm{~d}, J=6.9)$ & \\
5 & $2.20(\mathrm{~m})$ & 33.8 \\
& $1.96(\mathrm{~m})$ & 34.7 \\
6 & $2.60(\mathrm{ddd}, J=4.5,8.0,16.8)$ & 185.5 \\
7 & $2.39(\mathrm{ddd}, J=4.5,8.4,16.8)$ & 146.3 \\
$7 \mathrm{a}$ & $-\quad-\quad 24.8$ \\
191 & $2.46(\mathrm{t}, J=7.3)$ & 22.1 \\
10 & $1.57(\mathrm{tq}, J=7.3, J=7.3)$ & 14.1 \\
\hline
\end{tabular}

DMSO- $d_{6}, 400 \mathrm{MHz}$. chloride $(5.6 \mu 1,30 \mu \mathrm{mol})$ were added and stirred at $27^{\circ} \mathrm{C}$ for 12 hours. Further purification of the $(R)$ - and (S)-MTPA esters of auxofuran was accomplished by preparative HPLC using RP- 18 with a gradient of $\mathrm{H}_{2} \mathrm{O}+0.1 \%$ formic acid and $\mathrm{MeCN}+0.1 \%$ formic acid from $20 \% \mathrm{~B}$ to $100 \% \mathrm{~B}$, with the MTPA esters eluting at $80 \%$ B. ( $R$ )-MTPA ester of auxofuran: ${ }^{1} \mathrm{H}$ NMR (400 MHz, DMSO- $\left.d_{6}\right): \delta 7.80(1 \mathrm{H}, \mathrm{H}-$ 2), $6.31(1 \mathrm{H}, \mathrm{H}-4), 2.56$ (1H, H-5a), 2.32 (1H, H-5b), 2.55 (2H, H-6), 2.08 (2H, H-8), 1.34 (2H, H-9), 0.75 (3H, H10), $3.52\left(3 \mathrm{H}, \mathrm{O}-\mathrm{CH}_{3}\right), 7.47$ (5H, phenyl)). ( $S$ )-MTPA ester of auxofuran: ${ }^{1} \mathrm{H}$ NMR $\left(400 \mathrm{MHz}, \mathrm{DMSO}-d_{6}\right): \delta 7.89(1 \mathrm{H}$, H-2), 6.35 (1H, H-4), 2.49 (1H, H-5a), 2.25 (1H, H-5b), $2.48(1 \mathrm{H}, \mathrm{H}-6), 2.36(2 \mathrm{H}, \mathrm{H}-8), 1.52$ (2H, H-9), $0.88(3 \mathrm{H}$, $\mathrm{H}-10), 3.41\left(3 \mathrm{H}, \mathrm{O}-\mathrm{CH}_{3}\right), 7.46$ (5H, phenyl).

For the $(S)$-MTPA ester, compared to the $(R)$-MTPA ester, H-5 and H-6 exhibit an upfield shift, whereas H-2, H-8, and H-9 exhibit a downfield shift, suggesting an $S$-configuration at C-4.

Due to the absence of the hydroxy proton in $\mathrm{MeOH}-d_{6}$, the hydroxy and the keto group were inadvertently assigned wrongly at first [3]. 5,6-dihydro-4-hydroxy-3-propyl-4Hbenzofuran-7-one is a previously unknown natural product. Due to its similarity to indole-3-acetic acid, the most important native auxin, it was named auxofuran. Auxofuran also bears structural resemblance to ulufuranol (2) [8] and the herbicidal active koninginin B (3) [9] (Fig. 1).

Auxofuran is the first fungal growth promoting substance from a mycorrhiza helper bacterium belonging to the genus Streptomyces that has been characterized. As described in [3], auxofuran improves fungal growth and ectomycorrhiza

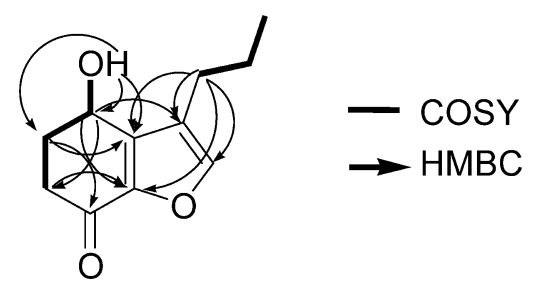

Fig. $2{ }^{1} \mathrm{H}^{-1} \mathrm{H}$ COSY and selected $\mathrm{HMBC}$ correlations of auxofuran (1).

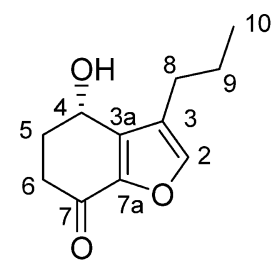

1<smiles>CCCc1coc2c1C[C@H](O)[C@H](O)C2</smiles>

2<smiles>CCCCCCC(O)C1CCC2=C(O1)C(O)CCC2=O</smiles>

3

Fig. 1 Structures of auxofuran (1), ulufuranol (2), and koninginin B (3). 
formation between $A$. muscaria and spruce. On the other hand, co-cultivation of auxofuran producing strain $\mathrm{AcH} 505$ and $A$. muscaria stimulated auxofuran production.

Acknowledgments The compounds were kindly provided by Prof. Hans-Peter Fiedler, University of Tübingen/Germany. His support for the project is appreciated very much. We thank Mr. Graeme Nicholson for obtaining the FT-ICR spectra. The work was supported by a research grant of the Emmy-Noether program (SU-239/2) of the DFG and the Schering AG, Germany.

\section{References}

1. Garbaye J. Helper bacteria: a new dimension to the mycorrhizal symbiosis. New Phytologist 128: 197-210 (1994)

2. Maier A, Riedlinger J, Fiedler H-P, Hampp R. Actinomycetales bacteria from a spruce stand: characterization and effects on growth of root symbiontic, and plant parasitic soil fungi in dual culture. Mycol Progr 3: 129-136 (2004)

3. Riedlinger J, Schrey SD, Tarkka MT, Hampp R, Kapur M, Fiedler HP. Auxofuran, a novel metabolite that stimulates the growth of fly agaric, is produced by the mycorrhiza helper bacterium Streptomyces strain AcH 505. Appl Environ Microbiol 72: 3550-3557 (2006)

4. Schrey SD, Schellhammer M, Ecke M, Hampp R, Tarkka MT. Mycorrhiza helper bacterium Streptomyces AcH 505 induces differential gene expression in the ectomycorrhizal fungus Amanita muscaria. New Phytologist 168: 205-216 (2005)

5. Dictionary of Natural Products on CD-ROM Version 14.2, Chapman \& Hall, London, (2005)

6. Scifinder Scholar, American Chemical Society, (2006)

7. Dale JA, Mosher HS. Nuclear magnetic resonance enantiomer reagents. Configurational correlations via nuclear magnetic resonance chemicals shifts of diastereomeric mandelate, $O$-methylmandelate, and alphamethoxy-alpha-(trifluoromethyl)phenylacetate (MTPA) esters. J Am Chem Soc 95: 512-519 (1973)

8. Henne P, Grabley S, Thiericke R, A. Z. Ulupyrinone and ulufuranol: new heteroaromatic metabolites from Streptomyces spina. Liebigs Ann/Recueil 5: 937-939 (1997)

9. Cutler HG, Himmelsbach DS, Yagen B, Arrendale RF, Jacyno JM, Cole PD, Cox RH. Koninginin B: a biologically active congener of koninginin A from Trichoderma koningii. J Agric Food Chem 39: 977-980 (1991) 